\title{
STUDI KOMPARATIF TENTANG KUALITAS PELAYANAN DI FAMILY FITNESS CABANG CAMBRIDGE CITY SQUARE DAN FAMILY FITNESS CABANG CENTRE POINT KOTA MEDAN
}

\author{
Oleh \\ Tommy Parningotan Hutabarat ${ }^{1}$, Syamsul Gultom ${ }^{2}$ \\ ${ }^{1}$ Fakultas Ilmu Keolahragaan Universitas Negeri Medan \\ ${ }^{2}$ Fakultas Ilmu Keolahragaan Universitas Negeri Medan \\ Email: tommyph@gmail.com
}

\begin{abstract}
Abstrak
Tujuan Penelitian ini adalah untuk mengetahui adakah perbedaan kualitas pelayanan antara Family Fitness Cambridge City Square (CCS) dan Family Fitness Centre Point (CP). Metode penelitian yang digunakan dalam penelitian ini adalah metode komparatif. Populasi dalam penelitian adalah berjumlah 700 orang untuk Family Fitness CCS dan 500 orang untuk Family Fitness CP. Jumlah sampel 60 orang dengan perincian 30 orang dari masing-masing club yang secara kebetulan dijumpai saat dilakukan pengumpulan data (accidental sampling). Instrument penelitian untuk pengumpulkan data dengan melakukan penyebaran angket. Penelitian ini melihat perbedaan kualitas pelayanan antara Family Fitness CCS dan Family Fitness CP dengan menggunakan perhitungan statistik uji-t . Setelah data terkumpul dilakukan analisis hipotesis hasil perhitungan angket Family Fitness CCS diperoleh thitung $=0,034$ bila dibanding dengan $t_{\text {tabel }}$ yaitu 2,020 pada taraf signifikan $5 \%$ dan $d k=30+30-2=58$. Karena $\mathrm{dk}=58$ berada di antara $\mathrm{dk}=40 \mathrm{dan} \mathrm{dk}=60$ maka dilakukan interpolasi sehingga diperoleh nilai $t_{\text {tabel }}$ sebesar 2,020 . Karena $t_{\text {hitung }}(0,034)>t_{\text {tabel }}(2,020)$ maka $\mathrm{H}_{0}$ diterima dan $\mathrm{H}_{\mathrm{a}}$ ditolak. Berdasarkan hasil pengujian hipotesis dan pembahasan penelitian, maka terdapat beberapa kesimpulan sebagai berikut: 1) Kualitas pelayanan Family Fitness CCS tergolong sangat baik untuk kategori Reliability, serta tergolong baik untuk kategori Tangibility, Responsivenes, Assurance dan Empathy. 2) Kualitas pelayanan Family Fitness CP tergolong sangat baik untuk kategori Tangibility, Reliability, dan Empathy, sedangkan Assurance, dan Responsivenes tergolong baik. 3) Tidak ada perbedaan yang bermakna antara kualitas pelayanan Family Fitness CCS dan Family Fitness CP kota Medan.
\end{abstract}

Kata Kunci : Komparatif, Kualitas Pelayanan

\section{A. PENDAHULUAN}

Seiring bertambahnya usia dan semakin bertambah padatnya aktivitas yang dijalani seseorang, semakin menurun pula tingkat kesadaran seseorang itu akan pentingnya berolahraga sebagai kebutuhan sehari-hari bagi kesehatan tubuhnya. Walau dengan uang yang banyak dapat membeli segalanya, tetapi kunci kebahagiaan yang paling penting adalah kesehatan. Dengan badan yang sehat dapat melakukan apa saja 
untuk menikmati hidup termasuk mencari uang, maka kesehatan harus dijaga karena sehat mahal harganya. Untuk menjaga kesehatan tubuh dan mendapatkan kebahagiaan.

Dengan semakin berkembangnya zaman menjadi lebih modern, diikuti pula dengan semakin berkembangnya tekhnologi yang lebih canggih. Tidak terkecuali dengan perkembangan alat-alat olahraga dengan basis tekhnologi canggih yang memberikan kelengkapan manfaat bagi tubuh dengan harga terjangkau, mudah ditemui di pasaran, mudah digunakan, dan disimpan. Sehingga dapat digunakan oleh orangorang sibuk dengan aktivitas hariannya yang tidak sempat berolahraga selama berjamjam. Makin banyaknya alat-alat olahraga yang mudah digunakan, alat olahraga yang sukar digunakan, berharga tidak murah, membutuhkan tempat yang luas untuk menyimpannya, serta dibutuhkan instruktur atau personal trainer yang berpengalaman untuk memantau penggunaannya menjadi sedikit terlupakan. Alat-alat olahraga tersebut biasanya terdapat di fitness center atau pusat kebugaran yang sering disebut dengan gym.

Berolahraga di tempat kebugaran (Fitness Center), menjadi salah satu pilihan tempat berolahraga masyarakat perkotaan, karena mereka dapat berolahraga tanpa merasa kepanasan dan tidak perlu banyak menyita waktu untuk mendapatkan bentuk tubuh ideal dan telah disediakan alat-alat kebugaran yang cukup memadai. Fitness Center menyediakan trainer (pelatih) yang telah berpengalaman dan ahli dalam bidangnya untuk membantu menentukan program latihan sesuai kebutuhan konsumen terutama dimaksudkan untuk membantu konsumen awam yang baru pertama kali berolahraga di pusat kebugaran. Kini fitness center menjadi kian popular bahkan sudah menjadi gaya hidup dikalangan masyarakat yang telah menyadari pentingnya berolahraga, tak terkecuali para wanita dan remaja.

Salah satu bentuk aktifitas yang dapat dilakukan perusahaan untuk bisa memperoleh posisi yang unggul dan berkualitas serta dapat bersaing, dalam upaya memberikan kualitas pelayanan baik, sering kali menjadi pertimbangan utama calon member dalam memilih fitness center. Adanya tuntutan pelayanan yang baik, sesuai dengan kebutuhan. Dengan demikian diharapkan konsumen akan mendapatkan kepuasan, yang selanjutnya akan mendorong pemakaian ulang jasa perusahaan, sehingga akan berdampak dan dapat mempengaruhi calon konsumen lainnya dalam 
memilih fitness center, sehingga minat masyarakat untuk berolahraga di fitness center meningkat.

Kualitas pelayanan merupakan aplikasi dari ketepatan dan keakuratan penyajian informasi serta akses data yang cepat. Disamping itu, pengelolaan sistem informasi juga berguna untuk lebih menjamin kualitas pelayanan yang baik dalam setiap proses yang dilakukan. Kurang optimalnya proses pemberian pelayanan yang berkualitas. Sehingga perlu adanya pembaharuan informasi yang tepat dan akurat untuk meningkatkan kualitas pelayanan yang akan diberikan. Dengan demikian, sistem informasi pelayanan menjadi faktor dominan dalam pengambilan keputusan untuk menciptakan sebuah proses pelayanan yang berkualitas serta meningkatkan minat konsumen.

Melihat tempat fitness berlomba untuk menarik para pelanggan dan melihat perkembangan Fitness Center di kota Medan yang begitu pesat, berskala besar dengan skala industri, berada di lokasi-lokasi pusat kota maupun pusat perbelanjaan di kota Medan., maka peneliti memilih salah satu tempat Fitness yang sepertinya ingin menguasai industri fitness di kota Medan yaitu "FAMILY FITNES". Dimana dilihat dari perkembangannya Family Fitness sudah memiliki enam cabang Fitness Center di kota medan, yang dapat kita temui di Cambridge City Square, Cemara Asri, Thamrin Plaza, Plaza Millenium, Medan Focal Point, dan Centre Point.

Melihat dari hal yang ditemukan oleh peneliti selama melakukan PKL (Praktek Kerja Lapangan) di Family Fitness, dijumpai beberapa hal yang membuat member sedikit protes karna jadwal kelas yang sering berubah tiap bulannya, adanya resepsionis (karyawan) yang tidak ramah terhadap member, kualitas air minum yang kurang baik, dan alat spinning yang kurang nyaman digunakan oleh member saat mengikuti kelas sehingga member tidak mendapat hasil yang maksimal. Masalah-masalah ini didapati dari setiap cabang Family Fitness. Sehingga, peneliti tertarik untuk melakukan studi komparatif karena ingin mengetahui apakah terdapat perbedaan kualitas pelayanan di antara setiap cabang Family Fitness dan dibatasi dengan hanya membandingkan dua tempat saja, yaitu di Family Fitness Cabang Cambridge City Square yang merupakan pusat Family Fitness dan Family Fitness Cabang Centre Point yang baru saja didirikan.

Oleh karena itu, berdasarkan hal-hal yang telah saya temukan dan kemukakan, maka saya sebagai peneliti mengambil keputusan untuk melakukan penelitian dengan tujuan untuk mencari perbedaan kualitas pelayanan antara Family Fitness Cabang 
Cambridge City Square dengan Family Fitness Cabang Centre Point dalam hal kualitas pelayanan di tempat fitness. Tujuan saya melakukan penelitian untuk bahan pembelajaran dalam hal kualitas pelayanan di tempat-tempat olahraga terkhusus tempat fitness bagi orang-orang yang akan membaca, serta menjadi pelajaran untuk perubahan terhadap suatu pelayanan di tempat fitness yang saya jadikan tempat penelitian dan bertujuan untuk mengukur besarnya dampak kualitas pelayanan Family Fitness sebagai salah satu dari organisasi yang bergerak dibidang jasa pelayanan di kota Medan.

\section{Kualitas Pelayanan}

Menurut Parasuraman, kualitas pelayanan merupakan perbandingan antara pelayanan yang dirasakan (persepsi) konsumen dengan kualitas pelayanan yang diharapkan konsumen. Jika kualitas pelayanan yang dirasakan sama atau melebihi kualitas pelayanan yang diharapkan, maka pelayanân dikatakan berkualitas dan memuaskan.

Dimensi kualitas pelayanan sangat berpengatuh pada harapah pelanggan dan kenyataan yang dihadapi pelanggan saat menggunakan jasa perusahaan. Oleh karena itu, peneliti menggunakan dimensi waktu menurut Zeithamal, Berry, dan Parasuraman dalam Tjiptono (2001) karena simple dan popular serta dapat digunakan untuk mengevaluasi. Jika nyatanya pelanggan menerima layanan yang melebihi harapan maka pelanggan akan mengatakan pelayanan perusahaan berkualitas.

\section{Family Fitness}

Family Fitness merupakan perusahaan yang bergerak di bidang kesehatan di bawah nanungan PT. FAMFIT BUGAR NUSANTARA yang berpusat di Cambridge City Square (J1. Letjen. S. Parman No.217), Medan 20112. Family Fitness merupakan fitness center yang memiliki cabang terbanyak di kota Medan, yang terdapat di Medan Focal Point (Jl. Setia Budi Indah 2 \{Ring Road\}, Medan 20133), Komplek Cemara Asri (Jl. Boulevard Timur No.8), Thamrin Plaza (Jl. Thamrin No. 75 R, Parkir Lantai 1), Millenium Plaza (Jl. Kapten Muslim No.16, Dwi Kora, Medan Helvetia) dan Centre Point (Jl. Jawa No.8, Gang Buntu, Medan Timur). Family Fitness juga banyak bekerja sama dengan ruko mall, café, dan restorant. 


\section{B. METODE PENELITIAN}

Lokasi penelitian dilaksanakan di Family Fitness Cambridge City Square (J1. Letjen. S. Parman No.217), Medan 20112 dan Centre Point (Jl. Jawa No.8, Gang Buntu), Medan Timur. Metode yang digunakan dalam penelitian ini adalah metode studi komparatif. Metode dalam penentuan sampel adalah non probability sampling menggunakan teknik accidental sampling. Yang dimaksud dengan accidental sampling pada penelitian ini adalah member kedua Fitness Center yang kebetulan ada atau dijumpai saat dilakukan pengumpulan data, dengan menyebarkan angket pada 60 responden dengan perincian 30 orang setiap cabang. Penelitian ini dilakukan untuk membandingkan persamaan dan perbedaan dua atau lebih fakta-fakta dan sifat-sifat objek yang diteliti berdasarkan kerangka pemikiran tertentu. Pada penelitian ini variabelnya masih mandiri tetapi untuk sampel lebih dari satu atau dalam waktu yang berbeda. Instrument yang digunakan dalam penelitián inf adalah angket.

Teknik pengumpulan data dalam penelitian ini adalah menggunakan angket tertutup. Angket ini sudah disediakan jawabannya, sehingga responden tinggal memilih jawaban tersebut sesuai dengan tanggapannya, dengan memberikan tanda check list $(\sqrt{ })$ pada kolom yang tersedia. Teknik ini sangat praktis karena responden hanya memilih derajat kesetujuan dengan menggunakan modifikasi dari skala Likert, yaitu: Sangat Baik (SB), Baik (B), Kurang Baik (KB), Sangat Kurang Baik (SKB).

Data akan dianalisis menggunakan persentase dengan rumus sebagai berikut:

$$
\mathrm{P}=\frac{f}{n} \times 100 \%
$$

Keterangan:

$\mathrm{P}=$ Presentasi yang dicari untuk setiap kategori pelayanan

$f=$ total skor pernyataan dari setiap individu untuk setiap kategori

$n=$ total skor maksimal setiap pernyataan untuk setiap kategori

Untuk menentukan kategori pengklasifikasian terhadap studi komparatif kualitas pelayanan Family Fitness cabang Cambridge City Square dan Family Fitness cabang Centre Point kota Medan dapat dikemukakan sebagai berikut:

$$
\begin{array}{ll}
80 \%-100 \% & =\text { Sangat baik } \\
60 \%-79 \% & =\text { Baik } \\
30 \%-59 \% & =\text { Sedang } \\
10 \%-29 \% & =\text { Kurang } \\
\text { Kurang dari 10\% } & =\text { Kurang sekali }
\end{array}
$$




\section{HASIL DAN PEMBAHASAN}

Berdasarkan hasil penilaian persentasi angket Family Fitness Cambridge City Square diperoleh bahwa pada indikator Tangibility untuk kategori sangat baik 14 orang $(46,7 \%)$ dan kategori baik 16 orang (53,3\%). Dengan demikian persentasi angket Family Fitness Cambridge City Square dari indikator Tangibility dengan rata-rata keseluruhan sebesar 25,53 atau 79,79\% yang dikategorikan dengan baik. Selanjutnya, pada indikator Reliability untuk kategori sangat baik 18 orang $(60,0 \%)$ dan kategori baik 12 orang (40,0\%). Dengan demikian persentasi angket Family Fitness Cambridge City Square dari indikator Reliability dengan rata-rata keseluruhan sebesar 26,27 atau $82,08 \%$ yang dikategorikan sangat baik. Kemudian pada indikator Responsivennes untuk kategori-sangat baik 14 orang $(46,7 \%)$, baik 14 orang $(46,7 \%)$ dan kategori sedang 2 orang $(6,6 \%)$. Dengan demikian persentasi angket Family Fitness Cambridge City Square dari indikator Responsivennes dengan/rata-rata keseluruhan sebesar 15,50 atau 77,50\% yang dikategorikan baik. Pada pelayanan Assurance untuk kategori sangat baik 13 orang $(43,3 \%)$, baik 15 orang $(50,0 \%)$ dan kategori sedang 2 orang $(6,7 \%)$. Dengan demikian persentasi angket Family Fitness Cambridge City Square dari indikator Assurance dengan rata-rata keseluruhan sebesar 22,13 atau 79,05\% yang dikategorikan baik. Pada pelayanan Empathy untuk kategori sangat baik 14 orang $(46,7 \%)$, baik 13 orang $(43,3 \%)$ dan kategori sedang 3 orang (10,0\%). Dengan demikian persentasi angket Family Fitness Cambridge City Square dari indikator Empathy dengan rata-rata keseluruhan sebesar 22,07 atau 78,81\% yang dikategorikan baik.

Berdasarkan hasil penilaian persentasi angket Family Fitness Centre Point diperoleh bahwa pada indikator pelayanan Tangibility untuk kategori sangat baik 19 orang $(63,3 \%)$, dan baik 11 orang (56,7\%). Dengan demikian persentasi angket Family Fitness Centre Point dari indikator Tangibility dengan rata-rata keseluruhan sebesar 26,10 atau $81,56 \%$ yang dikategorikan dengan sangat baik. Selanjutnya, pada pelayanan Reliability untuk kategori sangat baik 19 orang (63,3\%), baik 10 orang (33,3\%) dan kurang 1 orang (3,3\%). Dengan demikian persentasi angket Family Fitness Centre Point dari indikator Reliability dengan rata-rata keseluruhan sebesar 26,60 atau 83,13\% yang dikategorikan dengan sangat baik. Kemudian pada pelayanan Responsivennes untuk kategori sangat baik 16 orang (53,3\%), kategori baik 12 orang $(40,0 \%)$ dan sedang 2 orang $(6,7 \%)$. Dengan demikian persentasi angket Family Fitness Centre Point dari 
indikator Responsivennes dengan rata-rata keseluruhan sebesar 15,83 atau $79,17 \%$ yang dikategorikan sangat baik. Pada indikator pelayanan Assurance untuk kategori sangat baik 9 orang $(30,0 \%)$, dan baik 21 orang $(70,0 \%)$. Dengan demikian persentasi angket Family Fitness Centre Point dari indikator Assurance dengan rata-rata keseluruhan sebesar 22,23 atau 79,40\% yang dikategorikan baik. Pada indikator pelayanan Empathy untuk kategori sangat baik 11 orang $(36,7 \%)$, baik 18 orang $(60,0 \%)$ dan kategori sedang 1 orang $(3,3 \%)$. Dengan demikian persentasi angket Family Fitness Centre Point dari indikator Empathy dengan rata-rata keseluruhan sebesar 22,43 atau 80,12\% yang dikategorikan baik.

Berdasarkan hasil uji-t tidak berpasangan (uji t independent sample t-test) diperoleh bahwa terdapat perbedaan yang tidak bermakna (tidak signifikan) perolehan kualitas pelayanan di Family Fitness Cambridge City Square dengan Family Fitness Centre Point. Hasil tersebut ditunjukkan berdasarkan hasil analisis uji-t independent sample t-test hasil pelayanan Tanglibility di kedua club. Hasil rata-rata/Tangibility pada Family Fitness Cambridge City Square sebesar 25,53 dan tangibility pada kelompok Family Fitness Centre Point kota Medan sebesar 26,10. Hasil uji statistik diperoleh nilai $\mathrm{p}=0,353$. Karena nilai $\mathrm{p}>0,05$ berarti dapat diambil kesimpulan bahwa terdapat perbedaan yang tidak bermakna (tidak signifikan) kualitas pelayanan Tangibility antara Family Fitness Cambridge City Square dan Family Fitness Centre Point kota Medan.

Hasil analisis uji-t independent sample t-test pada indikator pelayanan Reliability di kedua $c l u b$ diperoleh rata-rata Reliability pada Family Fitness Cambridge City Square sebesar 26,27 dan Reliability pada kelompok Family Fitness Centre Point kota Medan sebesar 26,60. Hasil uji statistik diperoleh nilai $p=0,812$. Karena nilai $p>$ 0,05 berarti dapat diambil kesimpulan bahwa terdapat perbedaan yang tidak bermakna (tidak signifikan) kualitas pelayanan Reliability antara Family Fitness Cambridge City Square dan Family Fitness Centre Point kota Medan.

Hasil analisis uji-t independent sample t-test dari pelayanan Responsivennes di kedua $c l u b$ diperoleh rata-rata Responsivennes pada Family Fitness Cambridge City Square sebesar 15,50 dan Responsivennes pada kelompok Family Fitness Centre Point kota Medan sebesar 15,83. Hasil uji statistik diperoleh nilai $\mathrm{p}=0,452$. Karena nilai $\mathrm{p}>$ 0,05 berarti dapat diambil kesimpulan bahwa terdapat perbedaan yang tidak bermakna 
(tidak signifikan) kualitas pelayanan Responsivennes antara Family Fitness Cambridge City Square dan Family Fitness Centre Point kota Medan.

Hasil analisis uji-t independent sample t-test pada pelayanan Assurance di kedua club diperoleh rata-rata Assurance pada Family Fitness Cambridge City Square sebesar 22,13 dan Assurance pada kelompok Family Fitness Centre Point kota Medan sebesar 22,23. Hasil uji statistik diperoleh nilai $\mathrm{p}=0,768$. Karena nilai $\mathrm{p}>0,05$ berarti dapat diambil kesimpulan bahwa terdapat perbedaan yang tidak bermakna (tidak signifikan) kualitas pelayanan Assurance antara Family Fitness Cambridge City Square dan Family Fitness Centre Point kota Medan.

Hasil analisis uji-t independent sample t-test hasil pelayanan Empathy di kedua club diperoleh-rata-rata Empathy pada Family Fitness Cambridge City Square sebesar 22,07 dan Empathy pada kelompok Family Fitness Centre Point kota Medan sebesar 22,43 . Hasil uji statistik diperoleh nilai $p=0,911$. Karena nilai $p>0,05$ berarti dapat diambil kesimpulan bahwa terdapat perbedaan yahg tidak bermakna (tidak signifikan) kualitas pelayanan Empathy antara Family Fitness Cambridge City Square dan Family Fitness Centre Point kota Medan.

Dilihat dari data pada tabel 4.7, kualitas pelayanan di Family Fitness Cambridge City Square tergolong baik. Keunggulan yang didapati dari Family Fitness Cambridge City Square dari kelima kategori kualitas pelayanan terletak pada Reliability (kehandalan), yang mencakup jam operasional club, penyediaan informasi, dan Personal Trainer. Dimana dari 30 responden, 18 orang menyatakan sangat baik dan selebihnya mengatakan baik. Hal yang perlu diperhatikan yaitu pada kategori kualitas layanan Responsivennes (daya tanggap), Assurance (jaminan), Empathy (empati), karena pada ketiga kategori ini masih ada responden yang member nilai sedang dan mungkin belum cukup merasa puas. Adapun ketiga kategori pelayanan ini terdiri dari cara yang diberikan oleh karyawan untuk member tanggapan terhadap keluhan member, kesiapan karyawan membantu member yang mengalami kesulitan saat melakukan latihan, dan keramah-tamahan karyawan.

Adapun kualitas pelayanan di Family Fitness Centre Point dilihat dari tabel 4.13 tergolong sangat baik. Dari kelima kategori kualitas pelayanan, tiga kategori yang terdiri dari Tangibility, Reliability, dan Empathy tergolong sangat baik. Serta untuk dua kategori lainnya yang terdiri dari Assurance dan Responsivenes tergolong baik. 


\section{KESIMPULAN}

1. Kualitas pelayanan Family Fitness Cambridge City Square tergolong sangat baik untuk kategori Reliability, serta tergolong baik untuk kategori Tangibility, Responsivenes, Assurance dan Empathy.

2. Kualitas pelayanan Family Fitness Centre Point tergolong sangat baik untuk kategori Tangibility, Reliability, dan Empathy, sedangkan Assurance, dan Responsivenes tergolong baik.

3. Tidak ada perbedaan yang bermakna antara kualitas pelayanan Family Fitness Cambridge City Square dan Family Fitness Centre Point kota Medan.

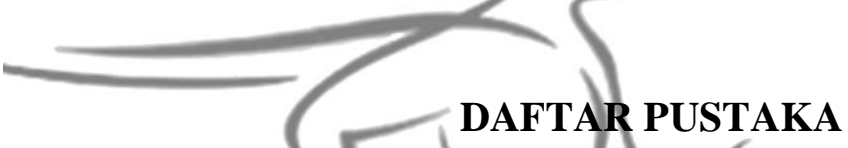

Arikunto, Suharsimi. (2006). Prosedur penetitian. Suatu Pendekatan Praktik. Jakarta: Rineka Cipta.

Rineka Cipta. (2010). Prosedur Penelitian: Sudtu Pendekatan Praktik. Jakarta:

Kotler, Philip. (1998). Manajemen Pemasaran: Analisis, Perencanaan, Implementasi, dan Kontrol (terjemahan Hendra Teguh dan Ronny Antonius Rusli). Jakarta: Prenhallindo.

Manullang, M. (2006). Dasar-dasar Manajemen. Yogyakarta: Gadjah Mada University Press.

Ndharu, Lelono. (2008). Kualitas Pelayanan Club Arena Fitness Center Hotel Melia Purosani Yogyakarta. Skripsi. Yogyakarta: FIK UNY.

Nugroho, Sigit. (2009). Tingkat Kepuasan Anggota Pusat Kebugaran terhadap Kualitas Jasa Pelayanan Di D'MUSCLE MANIA XX GYM FITNESS AND AEROBIC YOGYAKARTA. Skripsi. Yogyakarta: FIK UNY.

Sugiyono. (2011). Metode Penelitian Kuantitatif Kuliatatif dan R\&D. Bandung: Alfabeta.

Tjiptono Fandy. (2006). Manajemen Jasa. Yogyakarta: Andi Offset.

Yamit, Z. (2001). Manajemen Kualitas Produk dan Jasa. Yogyakarta: Ekonisia. (2003). Manajemen Produksi dan Operasi. Yogyakarta: Ekonosia

Yudik Prasetyo. (2004). Persepsi Anggota Klinik Kebugaran FIK UNY terhadap Kualitas Jasa Pelayanan. Skripsi. Yogyakarta: FIK UNY.

Yuliasih. (2005). Analisis Kepuasan Members pada Kualitas Pelayanan Jasa Kartika Dewi Fitness Center. Skripsi. Yogyakarta: FIK UNY.

http://www.gofamfit.com (Family Fitness) 